\title{
Areas Of Modern Trade Policy Versus Economic Security
}

\section{Bogusława DRELICH-SKULSKA and Małgorzata Domiter}

\author{
Wroclaw University of Economics and Business, Wrocław, Poland \\ Correspondence should be addressed to: Bogusława Drelich; boguslawa.drelich-skulska@ue.wroc.pl
}

Received date: 21 January 2020; Accepted date: 6 July 2020 ; Published date: 26 February 2021

Academic Editor: Anna Sylwia Kowalska

Copyright (c) 2021. Bogusława DRELICH-SKULSKA and Małgorzata Domiter. Distributed under Creative Commons Attribution 4.0 International CC-BY 4.0

\begin{abstract}
The concept of economic security is not new. However, the awareness that the economic factor contributes to state security, or even constitutes its significant part, has been associated with the evolution of international relations throughout history. The following article identifies and describes the controversies and dilemmas arising from the economic security in conditions of the current growth of the world's economy. Viewing from the perspective of trade policy allows distinguishing three significant open subsets among them. These subsets exist in close mutual interdependence. The first is methodological referring to the paradigm of security in contemporary international relations. The second arises from the changes generated by globalization and regionalization. Simultaneously, the third one is linked to the ongoing civilizational change in the world of technology, the organization of the economic activity and the applied tools of trade policy.
\end{abstract}

Keywords: Economic Security, Trade Policy, International Relations, Development Dilemmas.

\section{Introduction}

The issue of security has become the focus of attention for politicians and scientists nowadays. It results from the dynamics of changes in the international relations system and the emergence of new economic powers. One of the approaches to security is represented by the Copenhagen
School, which is based on practically all the previous theoretical visions: realism,

idealism, studies of peace and conflict, and the proposals inspired by the critique of the earlier achievements. Bill McSweeney was the first to use the name of this approach in his review of the work carried out by the team led by Barry Buzan in the research center in Copenhagen. The 
Copenhagen school lists five main areas of contemporary security: economic security, social security, ecological security, political security and military security (Leszczyński, 2016, p. 83).

At the time of the dynamic changes connected with the construction of the new international order in conditions of hyperglobalization, it is essential to examine both the economic security and one of the factors shaping it, namely trade policy. Nevertheless, at present, it is difficult to answer the question as to what kind of trade policy should be implemented by countries in order to draw benefits from their economic growth, while at the same time avoiding the risk adherent to that process and the resulting decline in their economic security. The concepts of the current trade policy address these dilemmas of the policy of development.

The research aim of this article is to explain the need for analyzing the phenomenon of economic security in correlation with the implemented trade policy. Apart from the main objective, the article is also focused on accomplishing cognitive and methodological aims. The cognitive aim means defining the position and the significance of trade policy in shaping the new international order in the progressing globalization processes. The methodological aim is realized with the use of (1) a method compatible with a systemic approach to the research and verification of descriptive and statistical material, and (2) a procedure of ordering the process of examining the features and determinants of trade policy and their influence on the issues of growth and economic security. The authors applied the method of deductive and statistical analyses following the concept of a systemic approach. As a result, research problems have been solved, or at least their resolution has been approximated in a comprehensive and multi-aspect way. This method, despite its specific limitations, was accepted as the most suitable for describing and analyzing phenomena of such scope and complexity. In practice, the authors also used the method of critical analysis of the available literature (serving to present the theoretical basis of this matter) and the method of comparative analysis (used when comparing the results achieved by the tools of trade policy adopted in various countries at their diverse levels of development).

\section{Security and its models in contemporary international relations}

The modern concept of economic security is defined in a variety of ways, although there exists a shared conviction that the economic factor determines the possibilities of social and economic growth in conditions of globalization (Skulska, 2010, pp. 145-146). Following after $\mathrm{Z}$. Stachowiak (2012, p. 4), it can be said that these are: the resultant of the factors of the economic growth and its limitations; the state of the economy and its structure, and also the economical relations enabling an effective counteraction against negative external actions which are able to affect the stability of a state system, disrupt the economic growth or lower its defense potential; a general state of economic dependence defining the degree of effectiveness of the external economic interference in the internal economic growth; the reflection of the degree to which a given state is prone to the transference through the economic sphere - mostly through the channels and mechanisms of economic dependences actions of a political nature aimed at weakening the state security (energysupply blackmail, speculation on the currency market and money market); balancing development needs and the possibilities of their satisfaction.

According to K. Księżopolski, economic security means the uninterrupted functioning of economies, namely the sustaining of the fundamental indicators of growth and ensuring a comparative equilibrium with economies of other countries (Księżopolski, 2011, p. 24).

K. Kłosiński defines economic security as "the entirety of factors and conditions protecting the independence of the national economy, its stability and equilibrium, and also ensuring its 
capability for constant renewal and selfimprovement" (Kłosiński, 2006, p. 41). The above definition directs attention to the three-element structure of economic security:

Independence of economy: Naturally, this does not refer to achieving the conditions of autarchy but to establishing such a position in the international arena which enables it to compete freely and participate in the world trade on partnership terms, Stability and equilibrium in economy: The optimal conditions for the functioning of enterprises and the lack of significant disproportions in income redistribution,

Capability for constant renewal and selfimprovement: Ensuring an unfettered growth of investment and innovation.

It would be worth considering in depth the issue of an economy's independence in the context of economic security. In the era of a global economy, it is impossible, and at the same time, economically not viable to achieve the state of economic autarchy (self-sufficiency) because such a condition would exclude obtaining benefits from the international division of labor and foreign trade, as well as the advantages of scale due to production destined for export. Ensuring the independence of an economy is thus somewhat limited to achieving the conditions in which the economy of a given country benefits from the supply of production factors indispensable for its growth and functioning, and the complete freedom in realizing the objectives of the macroeconomic policy (Bobrow, Haliżak and Zięba, 1997, p.78).

On the other hand, the development of globalization and the increasingly deeper interdependencies between countries have led to a phenomenon in which the concern for sovereignty is delegated to the international level and described as pooling sovereignty (Żukrowska, 2003, pp. 188-189). An example of this phenomenon can be seen in individual EU member countries, which have ceded a part of their prerogatives onto a central authority. Legislative acts in the individual countries have to be adapted to EU laws based on the principle of precedence of the Community laws as one of the main rules in the European Union. The phenomenon of pooling sovereignty is also connected with the participation of individual countries in international organizations; for instance, members of OPEC are obliged to observe the limits of crude oil extraction set for their countries. A transfer of responsibility for one's sovereignty to the international level is, not only something positive which allows for the acceleration in making difficult decisions, but also advantageous in the long term.

Furthermore, it leads to the restriction of the decision-making field for individual countries, which, in certain circumstances, may bring disadvantages for individual entities. Decisions made on the international level are not always beneficial to all the interested parties, particularly those with a weaker bargaining power in the international arena. From the viewpoint of a country's economic security, equilibrium should be maintained between leaving decision-making competences at the level of a given country and delegating them to international bodies. There are several international organizations whose scope of activity is providing economic security in diverse areas, e.g., the International Monetary Fund, the World Bank Group, the World Trade Organization, and the OECD (Marzec, 2006, pp. 69-83).

The matter of economic security factors can be approached according to various criteria. Apart from analyzing this category on national and international levels, many other criteria for the classification of economic security threats can be considered. The first criterion refers to a localization of the threats to economic security. Those dangers can be either internal or external, but they might also have a deliberate, accidental, or stimulated character. The analysis of economic security threats can consider the ranges of their influence. In this context, economic security threats can be characterized by a narrow or wide reach. The durability of influence is the next measure that allows us to classify economic security destabilizing 
factors. Under this criterion, they can recede fast or slow using a policy aimed at counteracting it. Furthermore, the typology of threats that destabilize economic security considers the character of factors that trigger them. For instance, they can be triggered by factors of economic nature, the result of demographic changes, or the effect of political actions. The destabilizing factors can be divided based on the criterion of related costs, which allow for eliminating them expensive and with low outlay, those requiring external assistance or those limited to external intervention. The threats occur asymmetrically in a country's economy so that they can be divided in regards to the sector that is destabilized. For instance, their character can be financial, social, biological, or chemical, or they can affect the energy sector, natural environment, or access to the elements. The threats to a country's economic security can also be divided in terms of the phases of the business cycle that they affect. In this context, the threats can occur during the phase of depression and collapse (including, e.g., the supply shock), or the phase of recovery and growth (including, e.g., demand shock). Last but not least, the division of economic security threats is related to the social and political stability. Regarding this criterion, economic security can be destabilized in several aspects, including the level of unemployment, the share of persons living below the level of subsistence, the size of the grey economy, or the structure of employment and its sensitivity to the liberalization of the economy (Żukrowska, 2003).

The typology of economic security presented above suggests that this is a complex and multifaceted issue which may be considered based on various criteria, starting from the location of its threats, through costs, and ending with macroeconomic indicators such as the level of unemployment and the percentage of persons living below the level of subsistence.

The question of what constitutes the model for the formation of security is a question about the existence of the international security paradigm in the current international relations. The universal international security paradigm is normally defined as a set of features that are recognized as typical in the context of international security because they describe relations between the entities constituting the international community (Gryz, 2006, pp. 15-17). This assumption allows indicating a group of characteristics existing in the field of international security based on which, and in relation to which, the research model is constructed. These characteristics include:

The anarchy of the international environment which results from changes in the balance of power between the growth-oriented entities, usually as a result of political, economic, socio-cultural, and military rivalry (Buzan, 1984, p. 19)

Turbulence in the environment of international security resulting from the evolving nature of threats which, in conditions of deep interdependency, take on a political, economic, socio-cultural as well as a military character. Their existence prompts those entities to seek new forms of relationships, thanks to which they can - in a less or more formalized way - counteract these threats by increasing their security. In this context, it is worth recalling the comment by D. Shen, who said that the search for the appropriate forms of providing security de facto necessitates the creation of alliances of a different degree of institutionalization (Shen, 1994, pp. 165-179).

The sensitivity and susceptibility of entities to the negative impulses originating from the international environment result from the growing processes of international influences and interdependencies. The sensitivity and susceptibility in the part of the entity are also usually expressed by the ability to adapt, or not, to disadvantageous changes taking place in the international 
environment. In this context, it is worth recalling E. Haliżak, who stated that " $(.$.$) in international relations,$ just like in the whole system, there are constant actions on the part of some entities and the counteraction by others - the occurring actions and reactions define the dynamics of international relations" (Haliżak, 1997, pp. 7-23).

The international relations normativity defines the forms of the entities' activity, including the ways of ensuring their security. According to M. Pietraś, “(...) the norms define the general directions of conduct of a regime, and thus the standards of behavior, both in the category of rights and duties. At the same time, they do not have to be legally binding, although they are usually connected with certain multilateral agreements" (cf. Pietraś, 1996, p. 65).

The institutionalization of international relations involves all the spheres of activities by entities (usually states and organizations of international stature): political, economic, socio-cultural and security. In effect, the institutionalized model of cooperation becomes a particular example of the activity of those entities. It is worth underlining that the development of international relations in the aftermath of the Second World War has resulted in creating new organizational forms of cooperation between countries. These forms are the outcome of growing interdependences created by the structures of international influences represented by institutions and organizations, at the same time being the effect of international conditions which determine the state of individual countries through the processes of intermingling their internal and external spheres of activity. Simultaneously, the institutionalization

of international relations results from the state of conscience of nations, social groups, and units organized into states. The process of institutionalization involves the sphere of conscience and practice of society's life. They introduce order in which it is easier for the state to formulate its policies, thus gaining confidence in undertaking actions and becoming credible for its partners in the conditions of the transition from geopolitics to geoeconomics (cf. Gryz, 2004, p. 72).

This model can also be accepted as the appropriate one for the economic security study, with a particular consideration to the influence of trade policy on that matter.

\section{The place of trade policy and the world trade system in the theory of international relations and in shaping economic security}

The theory of international relations does not provide a clear interpretation of the role played by the world trade system. According to the realistic vision of these relations (European Union Politics, 2003, pp. 94-95), foreign policy is an outcome of the interaction between states, each of whom is focused on its interests in the anarchical international environment, which lacks the generally accepted rules of conduct, as well as the authority to enforce the elementary rule of law. In these conditions, states rationally determine their own goals, based on their military and economic position achieved in the world. Their most important goal is to survive despite the continuous rivalry in which there is no place for common interests. In its turn, neorealism represents the view that states, even when functioning in such conditions, can be interested in international cooperation and order of their mutual relations as far as this will allow them to strengthen the position among their rivals. To this end, the existence of regimes is useful because they facilitate the achievement of international agreements. These are games with a zero outcome, in which a division of the jointly accomplished benefits depends on the strength of individual countries. Due to 
those clashing interests, it is difficult for them when faced with the need to conduct their own foreign policy and act under pressure exerted by internal groups of interests, to construct healthy compromises in international relations (Świerkocki, 2007, pp. 232-235).

The crises experienced in recent years, especially the last financial and economic crisis, clearly indicate the weakness of public institutions and the effective mechanisms of prognosis and control, which leads one to reflect on the effective economic policies, and a new interpretation of the relationship between the state and the market. This is especially important when creating the new or reorganizing the already existing institutions responsible for shaping the economic security, which are equipped with the appropriate functions. Those particularly important include: regulating the human behavior in a way which does not result in joint damage or at least compensates for it; lowering the cost of transactions through simplifying contract procedures and access to the commodity market, organizing the process of information transfer, and facilitating a learning process (Stachowiak, 2012, p. 108). Regarding the issue of the role of the state and the relation of state-market, it should be stressed that the high mobility of the transnational capital imposes a reorientation of the role and functions of the traditionally interpreted nation-state, which is gradually evolving into a 'neoliberal' state while losing its attributes of real influence on economic processes.

At the same time, there is a paradox. Firstly, the growing importance of the economic security results from the rules of the liberal order in the world economy. However, on the other hand, the liberal economic doctrine and the world order created on its basis are a source of numerous threats to economic security (Haliżak, (a) 2005, p. 88). The principle of competitiveness is the condition of the market's effectiveness and, at the same time, a constant threat to all entities operating in that market. Thus, efficiency and effectiveness become the fundamental criteria of survival, and neglecting them poses a threat of failure for those entities and entire economies. However, economic security can be achieved due to state intervention and the policy of protectionism - in direct opposition to the theory and practice of liberalism. In international relations, this is represented by the fact that economic security threats do not result from shortcomings of the liberal order, but from its development and success, which leads to the growing inequalities in development. Therefore, they are the threats brought on by the market and free Trade (Haliżak, (b) 2005, p. 78).

Thus, a particular dichotomy of opinions arises in the current scientific discourse. One group of researchers sees a positive connection between the economic liberalization and the international ordersince in conditions of liberalism, there is a smaller number of conflicts occurring between states, and it is possible to see the positive effects of globalization on individual countries, measured with the Globalisation Index (Tures, 2004, pp. 423431). The second group of researchers' opinion is critical in regard to the practical implementation of the liberal order, such as the functioning of the World Trade Organisation. In their opinion, the international trade system which followed the creation of the WTO, instead of bringing benefits to everyone, has led to the petrification of the differences in development between states, mostly due to the unequal distribution of benefits created by the international trade (Stiglitz, 2004, pp. 52-55).

At this point, it would be worth considering whether it is possible to propose the thesis that economic security means, above all, the degree of influence on other foreign entities through economic activities which result from the character of the implemented policy, and whose purpose is to weaken the economy and the whole system of national security (Perczyński, 1985 , p. 95). This thesis is correct, yet it lacks the points of reference to activities carried out by the state in its territory and within its socio-economic system. Threats 
to economic security do not always arise due to external aggression. Frequently, erroneous decisions regarding a location of capital or trade policy lead to the weakening of the economy or its destabilization. Another element of a state's economic security is shaping the relations with other entities in the international arena and entering into trade relations both with countries and other entities in the international markets.

On the one hand, expanding business ties with foreign entities creates new possibilities. It opens up the existing ones for the economic growth through accessing new markets as well as various forms of capital, but on the other, it results in the threat of the occurrence of external factors which may have a negative impact on economic security (Sojka, Waloszczyk, 2008, pp. 82-83). With a highly developed network of business ties, there is an increased risk of the lack of total control over them, the loss of control over the flow of resources, and the imprecise absorption of information about the potential threats or attacks against a given community or economic system. There also arises a problem of excessive dependence on a single trade partner or a supplier in purchasing raw materials and energy. The unforeseen actions in such an entity may pose a severe threat to the state's security. In the literature on this subject, the problem of a significant impact on the socio-economic sphere of the state from the outside has been acknowledged as the most urgent one (Księżopolski, 2004, p. 51).

The place of trade policy in building the competitiveness of economies and their security

In the light of changing conditions in the international competition, there is a growing importance of policies supporting the internal adjustment of national economies to the requirements of the global economy.

The policy of supporting adjustment is defined as the "policy of structural adjustment (positive and negative), the policy of support for the adjustment of trade and also as the policy of competitiveness" (Zielińska-Głębocka, 1998, p. 197). In assuming the pace of adjustment as a criterion, one can distinguish three kinds of such a policy:

The policy of speeding up the pace of adjustment with the use of accelerators, e.g., liberalization of international transfers, promotion of scientific research, and support for the sector of SMEs,

The policy of favoring autonomous adjustment through creating catalysts of economic change, e.g., the rules of competition, the harmonization of norms and standards on the international scale, and the stabilized protection,

The policy of delaying (slowing down) the processes of adjustment by introducing brakes, e.g., customs and non-tariff barriers, restrictions in terms of FDI, subsidies of production, export, and regional.

The policy of acceleration, also referred to as the policy of positive structural adjustment, aims at supporting the economy in the processes of adjustment, while at the same time reducing the period necessary to implement changes. It means that a government accepts a changing situation in the international markets and strives to cope with the new conditions imposed by these changes. Such an attitude of the government favors the integration of the country into the global economy. The acceleration of those processes is connected with the costs of the adjustment, whose burden rests on the domestic entities and sectors of the economy. The dislike for such a policy in the part of the domestic environment usually appears when the short-term cost of adjustment is relatively high. This situation typically occurs when a country is in an unstable macroeconomic condition, which translates into the threat of inflation or recession. The lack of social acceptance for this process is demonstrated mostly by strong economic sectors or unionized interest groups which used to seek advantage of governmental interventionism and protectionism. However, the fact remains that lobbying on 
behalf of sectoral interests weakens the possibilities of conducting the policy of positive adjustment based on the principle of actions oriented at all business entities. The majority of countries described as industrialized aims at the positive adjustment policy, which is also recommended by the OECD. Council (OECD, 1993).

The strategy of delaying processes of adjustment is aimed at protecting the domestic economy of the country against the international competition, even at the cost of its disintegration from the world economy. This kind of policy is defined as a defensive policy or the policy of negative structural adjustment. It is aimed at slowing down the pace of changes and minimizing the short-term costs of the adjustment. Depending on the accepted level of restrictions, it may, although it does not have to, produce catalysts of change. In the decidedly restrictive strategies, the government does not place significant importance on ensuring the conditions for autonomous adjustment. In contrast, in the less restrictive strategies, there may appear catalysts in the form of clear rules of competition, adapting domestic standards to the global ones, and care for stabilizing regulations and legal norms.

In the negative policy, the focus is mostly on the stability of the production sector and the protected branches of industry (production of steel, textiles, clothing, shipbuilding, and coal mining), maintaining employment - in particular of low-qualified staff, and protection against foreign competitors. The sectoral instruments used in realizing the objectives of this policy include tax and credit preferences, government subsidies concerning production and investment, subsidizing exports, restricting the volume of imports, customs charges, quotas, and limits in the foreign investment. Thus, internal defensive policies are complemented by protectionist trade policy, aimed primarily at maintaining the existing competitiveness of the country in the international markets. In the long run, the negative policy is bound to bring negative results, mostly in the form of a slowdown in the pace of restructuring the economy and limiting the liberalization of the international trade. In the short term, it obtains popular support, mostly due to the stabilization of employment in the so-called 'difficult' sectors and the protection of branches in decline (Puślecki, 2000, pp. 39-44).

Tools of the adaptation policy include the macroeconomic, microeconomic, and structural tools, which belong to different types of government policies and can be divided into:

Sectoral - used to influence particular sectors of the economy,

Horizontal - addressed at various entities from different areas of business.

Horizontal instruments are used mainly with structural tools, e.g., those supporting industrial investment, scientific research, the SME sector, services linked with industry, tools concerning international trade (customs policy, non-tariff instruments, antidumping policy), and instruments for fighting against dishonest practices in trade and industry (Klamut, 2000, pp. 78-93).

Another division of these tools allows distinguishing the instruments of trade, industrial and regional policies, and competition.

The policy of adjustment requires building a comprehensive economic strategy with a high degree of cohesion between the individual types of policies. Some of them can be treated as substitutive (e.g., trade and industrial policies), while others as complementary (policy of positive adjustment and policy of competition). The nature of interdependencies between the policies should be decided by the objectives directing the whole strategy. If the strategic aim is the integration with a specific regional grouping, a particular importance is given to the set comprising trade policy, industrial policy, and policy of competition. When the definitive objective is of a social nature, such as fighting unemployment, improvement of the environment, or reducing regional disparities, a decisive set of policies consists of trade policy, industrial policy, regional policy, and policy of environmental protection. 
For the government activity aimed at improving the international competitiveness, a dominating set of policies is made up of trade policy, industrial policy, and microeconomic policy, particularly the exchange rate (Domiter, 2008, pp. 79-84).

These three sets of policies overlap if the country realizes all the goals mentioned above concurrently. Poland and Hungary can be considered as an example of economies which, during the period of market transformation, simultaneously liberalized trade and investment and aimed at EU integration. These objectives, in a way, imposed a parallel realization of broadly interpreted social aims, especially the reduction of regional differences, the improvement in the condition of the natural environment, and raising international competitiveness.

A structural character of the pro-export strategy depends on the activities aimed at increasing the share of exports in the economy. The primary aim of this strategy is to change the structure of the economy. Structural changes of an intentional proexport character involve two levels of transformation, intrasectoral and intersectoral.

The former, i.e., intrasectoral (macrostructural), is implemented within the sectors and is set out by the share of domestic and export sectors to create revenues of a country. At this level, it is essential to define what part of the national potential constitutes the element of the world system, and to what degree it meets its criteria of effectiveness, competitiveness and demand. A growing share of the export sector in a given economy indicates, but only apparently, its deep integration within the global system. An increase of this indicator may merely result from the decreasing size of production by the domestic economy, which thus contributes to the falling global production. As a result, although the export sector is not a dynamic part of the economy, an indicator of its internationalization will be rising. Therefore, when the production of the domestic sector is declining, and that of the export sector remains mostly unchanged, then the internationalization of the economy is only illusory. If the export sector constitutes a dynamic element of the economy and thus stimulates the growth of the given country's economy as well as that of the global economy, then the internalization achieved this way is of a real nature, determined by changes in the production volume and exports share in both that country's economy and in the global economy. The structure of the production of the export sector indicates the potential of the economy, which may be the subject of international integration. Particular importance is placed on the share of the exportable production in the overall export production; the higher it is, the greater the integration possibilities of a given economy are. Moreover, the domestic sector character and structure indicate its capability for being transformed into an exportable sector. The increasing volume of production and the share of exports in the economy are defined as pro-export restructuration, accompanied by shifting means of production between sectors and, thanks to the improved effectiveness of performance, the increase in the size of those resources (Wziątek-Kubiak (b), 1996, pp. 46-47).

The selective direction of a pro-export strategy is based on integrating a domestic economy within the global economy. Selectiveness in terms of this strategy means supporting selected business entities and, in this case, the entities in the export sector as the 'agent' in the intended structural changes. The selectiveness of this strategy is also reflected in a conscious choice of instruments and their selective implementation, i.e., only regarding exporters. Applying these instruments is to provide better conditions for the functioning of the exporters in relation to the producers for the domestic market (Wziątek-Kubiak (a), 1996, p. 50).

The fault of the accepted selective character of the pro-export strategy is the support for the production that is realized abroad and not for the effective production, which as a result, may distort or even make it impossible to achieve the fundamental aim of this strategy, namely the increase of 
competitiveness of the domestic production (Domiter, 2008, pp. 87-95). This effect may appear even though both the pro-export strategy and the policy of competitiveness share the same objectives of the effective allocation of resources and the inclusion of the economy in the global system. Nevertheless, the pro-export strategy concerns the changes in competitiveness between countries, and thus it is a method of development used by countries at a low level of development and low level of competitiveness of their production. This then leads to the elimination of differences in the level of competitiveness between countries. The scope of the policy of competitiveness is narrower and concerns the changes within a country aimed at increasing the effectiveness of production, while the result of a pro-export strategy is the development of only the export sector. The costs of implementing this strategy are borne by enterprises that do not export, among which there are often highly effective companies.

Consequently, the expansion is financed by them, often for the benefit of exporters with ineffective production. Moreover, the pro-export strategy does not address the consumers' interests, which are taken into consideration by the policy of competitiveness. External liberalization weakens the anti-consumer effects of the pro-export strategy (Brander, 1997, pp. 5070).

When constructing a model of the proexport strategy, it is justifiable to use additional criteria of selectiveness, not just the 'exportability' but also the effectiveness of production. The condition for providing a consistent level of support for all exporters is the inclusion of exported goods of both the private and social costs of production in the price (e.g., the costs of damage to the environment which are not incurred by direct producers). It is worth stressing that the costs of supporting exports are often also social costs, and therefore the effectiveness of such expenditure should be closely monitored.

Although the pro-export strategy and policy of competitiveness are mutually supportive towards each other and are also complementary in many aspects, their methods and aims can differ significantly. These policies may even have a negative impact on each other; for instance, support for many domestic exporters serves to increase their competitiveness on the global market, yet at the same time may result in - as in the case of South Korea monopolizing production and restricting competition in the domestic market.

The stress placed on the role of competitiveness and profitability of production when addressing the possibilities of integrating a domestic economy into the global system proves the supply-oriented nature of the pro-export strategy. This also means acknowledging the superiority of the supply determinants in the pro-export structural changes over the demand determinants (Krugman, Obstfeld, 2007, pp. 123-124). A vital element in the pro-export strategy is the assumption of the principle of the state's influence on the behavior of domestic producers, and not on those who buy their products. This results from the fact that export is the materialization of external demand, over which the government of an exporting country has no influence. The policy of an exporter's government is manifested only in the shaping of variables, which indirectly affect the demand for exports not just in the part of foreign customers but also the domestic ones. Depending on the demand conditions in the domestic market and relative prices, the exported production can be realized either in the domestic or a foreign market. It is linked to the existence of difficulties related to producing the effect of 'sucking out' the domestic production by foreign markets. In such a situation, it is justifiable to implement the strategy of 'pushing out' the exporter's production from the domestic market. This strategy also complements the policy of neutralizing anti-export stimuli in the economy. The mechanism of integrating the economy into the global system is stronger when the internal demand is smaller. This is connected with the scope of its pro-export restructuring, which is dependent on the 'suction' strength from abroad (so-called power of 
attraction) and not from the domestic market, and can be explained with the use of the following arguments:

The significant growth in the domestic demand satisfied by the newly launched production reduces the pressure on starting up exportable production. Expansion in domestic demand becomes a barrier for the development of the exportable sector,

The necessity of creating the effect of 'pushing out' is connected with the underdevelopment of the export sector, and in particular, its exportable part. When its share in the export sector is high, then pushing it out abroad takes place through the impact on the relative prices, whereas when it is small, supporting its development becomes a goal of the proexport strategy. In this situation, the favorable state of demand in the domestic market neutralizes the effect of such a policy,

Budgetary expenditure, due to its nature, stimulates growth in the domestic and not the foreign demand, which justifies the need to neutralize the 'suction' of the production stimulated by this spending into the domestic market. In the case of a country with a weak sector of exports, the state policy should be oriented on creating the effect of 'pushing out' production from that country.

A dynamic character of the pro-export strategy is the feature that distinguishes it from the pro-export policy. The latter, as has already been shown, is oriented on increasing the sales of the production abroad from the earlier constructed potential of production, but it does not require the development of exportable production. Without the implementation of investment processes that serve to develop such a production, there will be no stimulation for long-term structural changes. Without the development of new types of production and increase in manufacturing capabilities of the exportable production, there will be no place for the commencement of a dynamic restructuring, on which the expansion of integration links with the global system depends (Wziątek-Kubiak (b), 1996, pp. 53-54; Wziątek-Kubiak (a), 1996, pp. 2224).

The necessary condition for realizing a proexport strategy as a method of integration with the global system and structural reconstruction is not merely selectivity but also, primarily, the dynamism of the approach. This concerns the policy of allocating the resources of production means in the export sector of production, not just for export but also for that exportable, which also regards Poland. Support for the mechanisms of links with the global economy in countries undergoing economic transformation requires the neutralization of anti-export stimuli, both internally and internationally. The pro-export policy, which impacts shaping the proportions within the export sector, i.e., between its exported and exportable sections, is not able to achieve their neutralization alone. Therefore, one should rather talk about a pro-export strategy. The conditions for its implementation are a functioning reform and improvement in the development level of the market of production factors, as well as an institutional reform. This means that the development should be oriented mostly on the growth of the exportable production and involve elements of industrial policy, thus becoming a comprehensive activity. The realization of such a strategy requires countries to transform their economies, to carry out wide-ranging reforms, starting from the labor market (a reform of the tax and social security systems), the capital market (reducing the levels of inflation), and ending at the development of the information market and export infrastructure. Without these reforms, the potential for the development of exports, which already exists in these countries, would be quickly exhausted, with a slim chance for increasing their exportable production (Jeliński, 2003, p. 145).

\footnotetext{
Model assumptions of a pro-export development and its influence on the economic security of countries' economies
} 
A pro-export concept of growth can be realized with the use of one of the two possible directions:

Opening an economy to external influences -adjustment integration.

This results from external liberalization, which is meant to eradicate some domestic distortions brought on by the implementation of the strategy of substituting imports. Since these distortions originate in trade policy (especially in protection against imports), the removal of such protection becomes a method for eliminating the distortions in the markets of both the production factors and their effective allocation. This concept ignores the distortions resulting from underdevelopment, for instance, the institutional one and those of an international character. External liberalization stimulating domestic entities to become active on the international market does not neutralize the anti-export consequences of the distortions in the global market. Thus adjustment integration constitutes one of the aspects of the proexport strategy, and it is specifically synonymous with a narrow interpretation of this strategy (Krugman, Obsfeld, 2007, pp. 372-374),

External expansion of domestic entities active integration.

External liberalization, owing to eliminating domestic distortions, facilitates the foreign expansion of domestic subjects. However, this strategy is challenging to implement in underdeveloped countries and those characteristics for distortions of the institutional are the basis for the international integration. This strategy reflects a wide range of its interpretations, i. e., has to include the methods of neutralizing the anti-export objections of the domestic and the world market alike, and on the other hand, the methods of eliminating the reluctance of the global economy to absorb the production of the 'newcomers'. Thus, expansive integration has to be accompanied by external liberalization. When remaining at a low level, expansive integration can be realized providing that its anti-export consequences will be neutralized by exporters. While in the conditions of its large share in the domestic sector economy, this would require conducting very active pro-export initiatives (Wziątek-Kubiak (b), 1998, pp. 55-56; Wziątek-Kubiak (a), 1998, pp. 2429).

The changes in the international division of labor have been greatly affected by the systemic and economic changes in the countries transforming their economies, mostly those of Central and Eastern Europe, based on the liberalization of the economy, especially trade. It is important to emphasize that Central and Eastern European countries are described as the emerging markets due to the structure of their market economies and the process of their gradual inclusion in the competitive global economy. These processes led to the trade integration with the European Community and resulted in the creation of new flows of exchange and the transfer of trade from the ex-Soviet bloc of countries (RWPG) to the EU member states. In turn, reducing trade barriers and opening up to foreign competition prompted the restructuring of these economies and undertaking activities to adjust the individual economic sectors, including exports. The transformation of the economies of Central and Eastern European countries is often compared to the changes implemented in the emerging markets of countries in Asia and South America. The original emerging markets (South Korea, Taiwan, Thailand, Singapore, Chile, and Malaysia) owed their success to their high rates of economic growth (over $4 \%$ a year), the introduction of a freemarket economy, opening up to international competition, reducing trade protectionism and applying the strategy of 'export-led growth'. In other words, their growth is driven by exports of industrial products (Rynarzewski, ZielińskaGłębocka, 2006, pp. 255-256).

A liberal model of the pro-export economic development is based on the reform of trade policy and exchange rate, as well as liberalizing the import of capital. In this model, the basis for activating an effective allocation of production factors, 
which then determine the direction of structural changes, is removing distortions from the economy, in particular, those of an economic and domestic nature. However, distortions resulting from underdevelopment and functioning of market mechanisms are being ignored. At the same time, for the countries which are liberalizing ties with abroad, this also leaves out the results of distortions of an international nature linked to the functioning of the global economy and policies of other countries. However, it is worth stressing that development trends and the condition of the world economy are of great importance for the effectiveness of the pro-export reorientation in a development strategy. In this way, liberalization tendencies facilitate an unmistakable reorientation of development (e.g., the pro-export type of development in Hong Kong, Singapore, South Korea, and Taiwan in the 1960s) (Wziątek-Kubiak, 1984, pp. 150-155).

The basis of the liberal model is external liberalization, above all of the imports of goods. The increased competition on the internal markets leads to the weakening of national monopolies, improves the effectiveness and competitiveness of production, and favors developing a specialisation. Removing import restrictions brings immediate effects to the economy and results in the development of the export sector, mainly through absorbing production factors freed from other sectors. Liberalizing imports is also demonstrated by lowering production costs in sectors that were protected in the past, whereas it has an indirect influence on the growth of exports. Its weak influence on the development of this sector can be explained mainly by creating the effect of 'pushing out' production from the domestic market abroad, which is not sufficient to trigger a dynamic mechanism of structural changes. Hence, the complementary functions in this model are taken over by the exchange rate policy.

The exchange rate policy serves mostly to protect the results in the current turnover balance and to strengthen the mechanism of the transfer of production factors. Trade liberalization should additionally strengthen the exchange policy, i.e., the real devaluation.

In the in-depth liberalization of foreign trade, the real devaluation of a domestic exchange rate takes on the role of protection against imports and the promotion of exports. As opposed to the trade policy, which is applied selectively, the policy of exchange rate has a general and uniform character in respect of all the goods being the subject of the international trade.

As shown by international experiences, the policy of real devaluation aimed at protecting exporters in the countries redirecting their development strategy quickly gets into conflict with the use of the exchange rate to slow down inflation. This, in turn, makes it impossible to maintain a competitive and stable exchange rate in the medium term, conditioning the development of the export sector. The casualties in this conflict are the producers of the export sector. Therefore, a need arises to coordinate the policy of exchange rate with the fiscal and monetary policies (in order to slow down inflation) and to find the instrument fulfilling the pro-export functions realized by the exchange rate (Stefański, 2000, pp. 39-43).

Fluctuations of the real exchange rate and pro-export policy by destabilizing relative prices make it challenging to identify comparative advantages; in decreasing the credibility of reforms, they do not encourage entities to invest in the export sector. At the same time, there appears a problem of triggering instruments of the industrial policy, especially the stimulation of investment in the export sector (Rosati, 1990, pp. 208-254). The liberal model of pro-export development takes on two forms:

Ultraliberal: Devoid of direct support for export. Export stimuli are contained exclusively in the policy of liberalizing imports and devaluing the real exchange rate. Countries temporarily realized this form of the model in Latin and South 
America (Krugman, Obsfeld, 2007, pp. 363374),

Moderate: Involving different forms of the active pro-export policy (Wziątek-Kubiak (b), 1996, pp. 69-73).

The basic assumption of the interventionist model of the pro-export strategy is the acknowledgment of the structural heterogeneity of weakly developed economies and of the global market, and their poor integration as well as the fact that market mechanisms alone, in the conditions of underdevelopment and distortions, do not ensure the effective allocation of production factors.

The interventionist model underlines the need to protect domestic commodity markets in the period of redirecting their development strategy. The functioning of these markets can be gradually liberalized. These assumptions originate from the acceptance of the thesis about the imperfect functioning of international markets. In effect, the international market does not generate a strong mechanism of 'suction' of the production in weakly developed countries, and its distortions disturb the functioning of such economies. Their external liberalization pace, being slower than in the liberal model, is explained by the existence of distortions in competition in the world markets. The proexport policy is meant to neutralize the negative consequences for the development of exports and protect their own and foreign markets.

Moreover, in this model, there are strong arguments for the need to develop the newly created production. In the conditions of the intense international competition and weak domestic production, there are only slim chances to create new, effective (in terms of international standards) types of production. This leads to the demand for conducting an industrial policy, which is supposed to stimulate accumulation, induce the improvement of quality and availability of production factors, and channel the available means to achieve the intended aims. In this model, a significant role is played by the policy of stimulating savings both at home and internationally, the policy of investment including technological and educational investments. Administrative means of control are also applied (Acocella, 2002, pp. 286-288).

The differences between the interventionist model of developing a proexport strategy and the strategy of import substitution are based mostly on the fact that in the latter, exports are indispensable for financing imports and that it does not register the anti-export consequences of protection. In the interventionist model, the pro-export policy is a form of industrial policy. To affect a pro-export reorientation of the economy, a whole range of means available in the state policies is being implemented: fiscal, financial, academic, institutional, educational, and the direct productive activity of the state. Trade and exchange rate policies are far less critical in that model than in the liberal one. The exchange rate policy is used mainly to stabilize the economy and not for its proexport restructuring. A high level of protection leads to the appreciation of the exchange rate, and the resulting negative consequences for the export sector have to be neutralized by an active pro-export policy. To protect the balance of payments, in conditions of overestimating the exchange rate, liberalization is not accelerated. The allocative effects of shaping exchange rates achieved in the liberal model in the interventionist model are obtained through other instruments of state policy.

In the liberal model, the rapid external liberalization of the commodity markets means that only the most effective segments of the economy can survive. As a result, companies that, up till then, were growing due to state protection go bankrupt, and thus the domestic sector shrinks both in the relative and absolute approach, while at the same time, exports are growing. Thus the liberal model is also the model of drastic selection on the microlevel. The effectiveness of its functioning has its origin in microeconomics.

In the interventionist model, the development of the export sector is not accompanied by the falling volume of production of the domestic sector. Its 
production is also growing, although not as fast as that of the export sector. The proexport restructuring is an outcome of the differentiation of the dynamics of growth between these sectors (Wziątek-Kubiak (b), 1006, p. 108). The general principles of the interventionist model were realized, albeit somehow differently, by South Korea and Brazil. The differences were mostly connected with the policy regarding production factors, especially the import of capital. In South Korea, the market of production factors was controlled by the state, and there was also the anticipation of the liberalization of the commodity markets, in particular the import of foreign capital, in relation to which a selective policy was conducted. In Brazil, there prevailed a liberal approach to importing foreign capital, which was treated as an element of realization of the externallyoriented option of development, as well as a source of capital and technology. Moreover, foreign companies were the direct beneficiaries of the export policy because they obtained export subsidies.

The interventionist pro-export model was realized starting from the 1960 s, i.e., during the time of favorable international conditions, which in itself is a particular paradox, since that model is characterized by its distrust towards the mechanism of functioning of the global economy (Kim, 1991, p. 33; Coes, 1001, p. 20; Stiglitz, Charlton, 2007, pp. 35-37).

\section{Liberalism or protectionism?}

Regarding the eternal discussion on the advantages of the liberal concepts over the interventionist ones and vice versa, one should mention those economists who, in the theoretical framework of international economic policies, rejected the assumption of the advantages of the free-market which is available to all the subjects of the global economy. R. Prebisch thought that international trade is the outcome of trade policies pursued by the most developed countries, defined as the center, and in his opinion, two processes are potentially possible. In the first process, the countries of the center, through the high level of their imports, create a high import demand for their products among the other subjects in the world economy. This brings an increase in trade links between countries that remain outside the center. In the other one, a diverse situation, when countries of the center demonstrate low import indicators, countries from outside the center have to restrict their imports from there and reduce their volume in their mutual relations.

Prebisch also rejected the thesis about the benefits from free trade for all the subjects in the world economy. In his opinion, the theory formulated by D. Ricardo restricts the possibilities of obtaining benefits from the technological progress by less developed countries. As a result, there exists an unequal trade exchange within the center-periphery system, where periphery countries face structural unemployment, lower domestic revenues, lack of equilibrium in the balance of trade, and worsening of the terms of trade. In the long run, the relative fall in prices of products exported by periphery countries (agricultural products and raw materials) in relation to the prices of products exported by countries of the center (industrial products) brings the situation where the periphery countries, in order to obtain the same ratio of imported goods, have to export increasing amounts of their products, i.e., the effect of worsening the terms of trade (Wróbel, 2005, p. 78). The described result constitutes the essence of the so-called Prebisch-Singer hypothesis. Similar conclusions were reached by the creators of the partial pauperization concept, VKRR Rao and H. Myint (Prebisch, 1961, p. 266).

The concept of Prebisch contributed to the still ongoing discussion which searches for an answer to the question of whether, in fact, developing countries are losing the basis for their economic security as a consequence of the world trade and the current form of the global economy. This discussion also concerns the justification for the policy of protectionism or liberalism. The neoliberal paradigm has become the main ideological force for managers and economists in the global economy, and also for politicians in the 
center countries. However, it turned out to be unable to solve the economic and social problems of peripheral economies. For the latter, it was the state interventionism that provided the answer.

On the other hand, there emerged opinions about the need for an evolution in the neoliberal model to improve the economic security of the poorest strata of society in the least developed economies. This requires the reform of governance in international institutions, and the improvement in their transparency and openness. International institutions, mostly those responsible for the world trade and international trade policy, should be reformed so that the benefits arising from the process of globalization become available to all the subjects in the global economy (Stiglitz, 2004, pp. 23-32).

\section{Conclusions}

This article showed the relations between trade policy and the security of a country. The concern about the goods shortage, or in other words, the psychosis of the fear about the lack of goods, have always constituted the premise for ensuring economic security for countries and individuals. These factors made the entities in the world market determined to strive for obtaining benefits from trade exchange, and thus for the best possible access to the structures of the global market. This, in turn, is linked to the comparative advantages which define the competitive position of individual countries in respect of other entities in the global market. The international competitiveness of a country signifies its ability to defeat competitors not only abroad but also in the domestic market. Market shares, which describe the participation of a country in the global export market, provide a synthetic measure of competitiveness. This is the reason why countries attach (or should do) such great importance to exports and the factors of their growth which create their development and shape their economic security.

\section{Acknowledgments}

The project is financed by the Ministry of Science and Higher Education in Poland under the program "Regional Initiative of Excellence" 2019-2022, project number 015/RID/2018/19, total funding amount 10721040.00 PLN.

\section{EndNotes}

The following article is based on the paper titled Economic security and contemporary trade policy. A contribution to discussion presented by the authors at the $35^{\text {th }}$ IBIMA Conference, 1-2 April 2020, Seville, Spain.

\section{References}

- Acocella, N., (2002) Zasady polityki gospodarczej, Wydawnictwo Naukowe PWN, Warszawa.

- Bobrow, D.B., Haliżak, E., and Zięba, R., (ed.) (1997) Bezpieczeństwo narodowe i międzynarodowe u schyłku XX wieku, Fundacja Studiów Międzynarodowych, Warszawa.

- Brander, J.A., (1997) Rationales for Strategic Trade and Industrial Policy, What Should Be Trade Policy Target? (in:) P. Krugman (ed.) Strategic Trade Policy and the New International Economics, The MIT Press, Cambridge, Massachusetts, London.

- Buzan, B., (1984) Peace, Power and Security: Contending Concepts in the Study of International Relations, Journal of Peace Research, 21 (2). pp. 109-125.

- Cini, M., and Borragan, N., (2003) European Union Politics, Oxford University Press, Oxford.

- Coes, D., (1991) Brazil: Precedents and Prospects in Foreign Trade (in:) Shepherd G., Langoni CG (eds.), Trade reform. Lessons from EightCountries, vol. 3.1, ICEG, San Francisco.

- Domiter, M., (2008) Eksport w doktrynie i polityce gospodarczej na tle procesów liberalizacyjnych i integracyjnych, Wydawnictwo Akademii Ekonomicznej we Wrocławiu, Wrocław.

- Fiszer, J., (ed.) (1996) Państwa narodowe w euroatlantyckich 
strukturach,Instytut Nauk Politycznych i Dziennikarstwa, Poznań.

- Gryz, J., (2004) Proces instytucjonalizacji stosunków transatlantyckich, Wydawnictwo Naukowe Scholar, Warszawa.

- Gryz, J., (2006) Współczesny paradygmat bezpieczeństwa międzynarodowego, Rocznik Bezpieczeństwa Międzynarodowego, 1, pp. 11-27.

- Haliżak, E., (1997) Demokratyczność systemu międzynarodowego? (in:) E. Haliżak, D. Popławski (eds.), Demokracja w stosunkach międzynarodowych, Wydawnictwo Naukowe SCHOLAR, Warszawa.

- Haliżak, E., (a) (2005) Ekonomiczny wymiar bezpieczeństwa narodowego i międzynarodowego, (in:) Porządek międzynarodowy u progu XXI wieku, R. Kuźniar (ed.), Wydawnictwa Uniwersytetu Warszawskiego, Warszawa.

- Haliżak, E., (b) (2005) Liberalna wizja porządku międzynarodowego (in:) Porządek międzynarodowy $u$ progu XXI wieku, R. Kuźniar (ed.), Wydawnictwa Uniwersytetu Warszawskiego, Warszawa.

- Jeliński, B., (2003) Polska polityka handlu zagranicznego $\mathrm{w}$ warunkach członkostwa w Unii Europejskiej, Uniwersytet Gdański, Gdańsk.

- Kim, S.K., (1991) Korea (in:) Michaely M., Papageosigu D., Choksi A., Liberalizing Foreign Trade: Korea, Philippines, and Singapore, vol.2, Blackwell, Oxford-Cambridge, Massachusetts.

- Klamut, M., (red.) (2000) Polityka budowy regionu konkurencyjnego: strategie, modele, postęp, Akademia Ekonomiczna we Wrocławiu, Wrocław.

- Kłosiński, K.A., (2006) Światowe determinanty bezpieczeństwa ekonomicznego, (in:) T. Guz, K.A. Kłosiński, P. Marzec, Bezpieczeństwo ekonomiczne państw, Polihymnia, Lublin - Tomaszów Lubelski.

- $\quad$ Krugman, P.R., and Obstfeld, M., (2007) Ekonomia międzynarodowa. Teoria i polityka, vol.1 and 2, Wydawnictwo Naukowe PWN, Warszawa.
- Księżopolski, $\quad$ K.M., $\quad$ (2004) Ekonomiczne zagrożenia bezpieczeństwa państwa. Metody i środki przeciwdziałania, Wydawnictwo Kolor Plus, Warszawa.

- Księżopolski, K.M., (2011) Bezpieczeństwo ekonomiczne, Elipsa, Warszawa.

- Leszczyński, M., (2016) Bezpieczeństwo ekonomiczne w dobie hiperglobalizacji, Nierówności Społeczne a Wzrost Gospodarczy, 47( 3), 36.

- Marzec, P., (2006) Stymulowanie bezpieczeństwa ekonomicznego przez organizacje międzynarodowe w świecie, (in:) T. Guz, K. A. Kłosiński, P. Marzec (eds.), Bezpieczeństwo ekonomiczne państw, Polihymnia, Lublin - Tomaszów Lubelski.

- OECD (1993) Positive adjustment policies. Managing structural change, Paris.

- Perczyński, M., (1985) Globalne uwarunkowania bezpieczeństwa ekonomicznego, Polski Instytut Spraw Międzynarodowych, Warszawa.

- Pietraś, M., (1996) Państwa narodowe wobec dynamiki procesów bezpieczeństwa (in:) J. Fiszer (ed.) Państwa narodowe w euroatlantyckich strukturach, Instytut Nauk Politycznych i Dziennikarstwa, Poznań.

- Prebisch, R., (1961) International Trade and Payments in an Area of Coexistence. Commercial Policy in the Underdeveloped Countries, (in:) World Trade Trends and Patterns, Washington.

- $\quad$ Puślecki, Z.W., (2000) Usuwanie barier w handlu międzynarodowym integrującej się Europy a presje protekcjonistyczne (in:) Drozdowicz Z., Puślecki Z.W. (eds.) Przezwyciężanie barier w integrującej się Europie, Wydawnictwo Fundacji Humaniora, Poznań.

- Rosati, D., (1990) Polityka proeksportowa, PWE, Warszawa.

- Rynarzewski, T., and ZielińskaGłębocka, A., (2006) Międzynarodowe stosunki gospodarcze. Teoriawymianyipolitykihandlumiędzy narodowego, PWN, Warszawa. 
- Shen, D., (1994) Can Alliances Combat Contemporary Threats? The Washington Quarterly, 27(2), pp. 165179.

- $\quad$ Skulska, B., (2010) Istota i płaszczyzny analizy bezpieczeństwa ekonomicznego, (in:) Bezpieczeństwo międzynarodowe $\mathrm{w}$ regionie Azji i Pacyfiku. Wybrane zagadnienia, B. Skulska, P. Skulski (eds.), Wydawnictwo Uniwersytetu Ekonomicznego we Wrocławiu, Wrocław.

- Sojka, J., Waloszczyk, E., (2008) Bezpieczeństwo ekonomiczne państwa w procesie globalizacji gospodarki, Wydawnictwo Uniwersytetu Wrocławskiego, Wrocław.

- Stachowiak, Z., (2012) Teoria i praktyka mechanizmu bezpieczeństwa ekonomicznego państwa. Ujęcie instytucjonalne, AON, Warszawa.

- Stefański, R., (2000) Środki polityki handlu zagranicznego jako narzędzia stabilizacji koniunktury gospodarczej, Wydawnictwo Akademii Ekonomicznej w Poznaniu, Poznań.

- $\quad$ Stiglitz, J.E., (2004) Globalizacja, PWN, Warszawa.

- $\quad$ Stiglitz, J.E., and Charlton, A., (2007) Fair trade. Szansa dla wszystkich, PWN, Warszawa.

- Świerkocki, J., (2007) Światowy system handlu - istota i przyczyny rozwoju, Acta UniveristatisLodziensis Folia Oeconomica, 204, pp. 225-241.
- Tures, J., (2004) Economic Liberalization and International Order, Cato Journal, 23(3), pp. 423-431.

- Wróbel, A., (2005) Raula Prebischa wizja gospodarki światowej i jego rola w rozwoju teorii wymiany międzynarodowej, (in:) Porządek międzynarodowy u progu XXI wieku, R. Kuźniar (ed.), Wydawnictwo Uniwersytetu Warszawskiego, Warszawa.

- Wziątek-Kubiak, A., (1984) Społecznoekonomiczne uwarunkowania międzynarodowej zdolności konkurencyjnej Japonii, Monografie i Opracowania, no. 153, SGPiS, Warszawa.

- Wziątek-Kubiak, A., (a) (1996) Doświadczenia międzynarodowe $\mathrm{w}$ realizacji proeksportowej strategii rozwoju, Instytut Nauk Ekonomicznych PAN, Warszawa.

- Wziątek-Kubiak, A., (b) (1996) Kontrowersje wokół proeksportowej strategii rozwoju, Poltext, Warszawa.

- Zielińska-Głębocka, A., (1998) Wprowadzenie do ekonomii międzynarodowej. Teoria handlu i polityki handlowe, Uniwersytet Gdański, Gdańsk.

- Żukrowska, K., (2003) Kryteria bezpieczeństwa ekonomicznego, (in:) S. Dębski, B. Górka-Winter (eds.), Kryteria bezpieczeństwa międzynarodowego państwa, PISM, Warszawa. 